\title{
EVALUATION OF RELEASE OF Diaeretiella rapae (M INTOSH) FOR CONTROLLING THE CRUCIFEROUS APHID, Brevicoryne brassicae L. ON CAULIFLOWER PLANTS AT SHARKIA GOVERNORATE, EGYPT. \\ Saleh, A. A. A. \\ Plant Protection Research Institute, Agric. Res. Center, Dokki , Giza, Egypt
}

\begin{abstract}
Rate of parasitism by the aphid parasitoid, Diaeretiella rapae ( $\mathrm{M}^{\prime}$ Intosh) on the cauliflower aphid, Brevicoryne brassicae L. as well the hyperparasitism on D. rapae were recorded, at Kafer Sakr district Sharkia Governorate during the two successive seasons 2010-11 and 2011-12. Total means of parasitism rates of $D$. rapae were 23.58 and $28.06 \%$ during the two successive seasons, respectively. The parasitoid, $D$. rapae was parasitized by two hyperparasitism species Pachyneuron sp. and Alloxysta $\mathrm{sp}$.The seasonal means of hyperparasitism percentage were 28.42 and $29.67 \%$ during period of study, respectively. The parasitoid density, in relation to that of host density, had influenced on percentage of parasitism. The highest percentage reached was $87.75 \%$ at $15 D$. rapae female parasitoids per cage and the minimum was $46.1 \%$ at three female adult per cage. On the other hand, the average parasitism ratios in green houses were 73.94, 60.74, 54.29 and 39.98 at the parasitoid host ratios $1: 4,1: 8,1: 12$ and $1: 16$ respectively. Meanwhile the average parasitism ratios in the field were $58.39,50.01$ and $32.49 \%$ at the parasitoid host ratio $1: 8,1: 12$ and in control during the period of release. The result revealed that the best control of $B$. brassicae population under green houses conditions was achieved using by the power predator prey ratio $(1: 4$ and $1: 8)$ after 28 days from releasing $D$. rapae. Finally the parasitoid $D$. rapae can be used as biological control agents $B$. brassicae in cauliflower plantation under green houses and under field conditions at the parasitoid host ratios of $1: 8$ and $1: 12$.
\end{abstract}

Keywords: Diaeretiella rapae, Brevicoryne brassicae, evaluation, percentage of parasitism.

\section{INTRODUCTION}

The aphid Brevicoryne brassicae L. is a major pest, on cruciferous plants, in several parts of the world, especially cabbage cauliflower and in Egypt (Herakly and Abou El-Ezz, 1970; Horn , 1989 and Saleh, 2000). The parasitoid Diaeretiella rapae was found to parasitize $B$. brassicae and some other aphid species all over the world (Hafez, 1965; Abou Fakar \& Kawar, 1998 and Saleh, 2008). D. rapae (M' Intosh) is attacked by hyperparasitism that reduce its beneficial role. Recorded hyperparasitoids on $D$. rapae in Egypt were Pachyneuron sp and Alloxysta minuta (Hafez, 1965; Herakly and Abou El Ezz, 1970, El-Maghraby, 1993 El-Naggar et al. 2008 and Saleh, 2008). Diaeretialla rapae is well known as potential bio-agent for many aphid species in different countries (Abou Fakar and Kawar, 1998 and Ragab et al. 2002). Diaeretialla rapae is an important primary parasitoid of a wide range of aphid species in the world and Egypt, including major aphid pests such as cabbage aphid Brevicoryne brassicae L., green peach aphid Myzus persicae Sulzer., Russian wheat aphid Diuraphis noxia Mord., Rhopalosiphum padi L. and Schizaphis graminum (Rondani), cotton aphid, Aphis gossypii Glover, broad bean aphid Aphis craccivora Koch., bird cherry-oat aphid R. padi and 
Saleh, A. A. A.

corn leaf aphid R. maidis (Fitch), reed plants aphid Hyalopterus pruni and oleander aphid, A. nerii (Elliott et al. , 1994; Pike et al., 1999, Saleh 2000\& 2004, El-Heneidy et al., 2006, Saleh et al. 2006 and Saleh \& Gatwary, 2007). The present study was conducted to survey the parasitoids associated with the cauliflower aphid $B$. brassicae and estimate the rates of parasitism and the role of $D$. rapae against $B$. brassicae at varying population densities under green houses and field conditions was evaluated.

\section{MATERIALS AND METHODS}

\section{1- Estimation of parasitism rates in the field:}

This work was carried out on cauliflower plants cultivated in about one feddan area located at Kafr Sakr district, Sharkia Governorate, Egypt, during 2010-10 and 2011-12, cauliflower seasons. Random weekly samples of eight infested cauliflower leaves/sample were picked, placed tight paper bags and transferred to the laboratory. All aphid individuals in an area of 20 square inches/leaf were counted. Aphids were fed on their host plant and kept in Petri dishes (50 aphid individuals /Petri-dish) until formation of mummies. The mummies were isolated and kept in small glass tubes until emergence of adult parasitoids. At the same time, all hyperparasitoid adults, that emerged from mummies, were counted, identified and the percentage of hyperparasitism was, also, calculated. The emerged parasitoids were mounted and identified the by Biological Control Department, ARC, Giza, Egypt. Percentage of parasitism was calculated as monthly means according to Ferrell and Stufkens (1990), also the percentage of adult's emergence and sex- ratio were calculated.

\section{2- Effect of parasitoid densities on parasitisation rate.}

\section{A. In the cages}

The parasitoid ( $D$. rapae) and the host (B. brassicae) were reared in the laboratory. Young potted cauliflower seedlings bearing about 200 hosts (of mixed age). The experiments were carried out in iron cages (100x60x60 $\mathrm{cm}$ ) using different parasitoid densities of $3,6,9,12$ and 15 per cage, freshly emerged mated females fully fed on honey solution. Mated female parasitoids were gently introduced into each cage kept for $24 \mathrm{~h}$. then the parasitoids were removed and the hosts were left until they mummified. After mummification, the mummies were gently placed, with part of leaves, on a moisted filter paper in marked Petri dishes. The mummies were observed until the adults emerged where those were sexed and recorded. Five replicates were performed for each parasitoid density.

\section{$B$. In the green house}

The green house area was $8 \mathrm{~m}$ long and $1 \mathrm{~m}$ wide and $2 \mathrm{~m}$ hight. This size was covered with muslin. Cauliflower was planted in the green houses. This investigation was carried out in many green houses to use them for trial mass production of parasitoids. The normal agricultural practices were applied and no chemicals controls were used during the whole experimental periods. The cultivated area was $32 \mathrm{~m}^{2}$ in four green houses in 2010-2011 seasons. Cauliflower was planted on 4 October Large-scale production system was established to rear parasitoid. This consisted of rearing 
laboratory containing cages, which were filled with potted plants. These plants were infested with aphids and then used to infest larger cages or houses $(1 \times 8 \mathrm{~m})$, which contained small plots cauliflower plants. When the plots were heavily infested with aphids, they were exposed to colonies of parasitoids. When mummies began to be observed the plants were cut and the mummies collected. The parasitoids were released in the field or green houses using cauliflower leaves carrying colonies of parasitized aphids. In this investigation about 15932 parasitoid mummies in 2010-2011. Four density levels of 1:4, 1:8, 1:12 and 1:16 were planned in four green houses for the parasitoid and its host ( $B$. brassicae) combination. The initial numbers of the parasitoid mummies and aphid nymphs used for each treatment were 5730: 22920, 3894: 31152, 3436: 41232 and 2872: 45952 individuals, respectively. Random samples of six leaves (20 square inches/leaf) infested with aphids were taken every four days and transferred to the laboratory in tight closed paper bags. All individuals from each aphid found on the host plant samples were counted. Aphids were fed on their natural hosts and kept in Petri dishes (50 aphid/Petri dish) until the formation of mummies. The mummies of aphid were isolated and kept separately in small glass tubes until the emergence of adult parasitoid. Aphid mummies (A), live aphids containing parasitoid larvae(B) (which were kept until the formation of mummies) and unparasitized aphids (c) were recorded. The percentage of parasitism were calculated according to Farrell and Stufkens (1990).

\section{In the field.}

$$
\% \text { Parasitism }=\frac{A+B}{A+B+C} \times 100
$$

Cauliflower was cultivated in 6 October in season 2011-2012 season. Two plots of $5 \mathrm{~m} \times 7 \mathrm{~m}$ each $\left(35 \mathrm{~m}^{2}\right)$ were used in this experiment. To estimate the percentage of parasitism on the cauliflower plants, the total number B.brassicae and mummified aphids were counted on the plants. The average number per plant and total number of plants in $3 \mathrm{~m}^{2}$ were recorded. An area of $\mathrm{m}^{2}$ was contained eight plants. Consequently, the expected number of B.brassicae and mummies (D. rapae) could multiply by the number of aphids per plant by the total numbers of plants per fadden. Two density levels of 1:8,1:12 were planned for the parasitoid and its host (B. brassicae) combination . The initial average numbers of the mummies and aphid nymphs was found 498:5984 in $\mathrm{m}^{2}(1: 12.02)$ to reached (1:8) it must add 250 mummies per $\mathrm{m}^{2}$. The total number was 8750 mummies . In the second plot the initial numbers of the mummies and aphid nymph was found $397: 5986$ in m2 must add in $35 \mathrm{~m}^{2}(1: 15.08)$ to reached (1:12) it must add 101 mummies per $\mathrm{m}^{2}$. The total number $35 \mathrm{~m}^{2}$ was 3535 mummies. Random samples of eight leaves (20 square inches/leaf) were taken every four days. All individuals from each aphid found on the host plant samples were counted. Aphids were fed on their natural hosts and kept in Petri dishes (50 aphid Petri dish until the formation of mummies. The mummies of aphid were isolated and kept separately in small glass tubes until the emergence of adult parasitoid. Aphid mummies (A), live aphids containing parasitoid larvae (B). 
Saleh, A. A. A.

The same sampling technique were taken in second cabbage field to compared the percentage of parasitism with release parasitoid and without release in the same time and in the same date

\section{RESULTS AND DISCUSSION}

\section{1- Role of $D$. rapae for controlling $B$. brassicae on cabbage.}

The weekly numbers in this study showed that two hyperparasitoid species Pachyneuron sp. and Alloxysta sp. were recorded in small numbers and it existed from 3th January to the end of the first season and from 17th January to the end of the second season. The primary parasitoid D. rapae was the most dominate species with high relative densities during the two successive seasons. The percentages of parasitism ranged from 4.70 to 56.85 during first season and from $3.94 \%$ to $65.85 \%$ during the second seasons. In the first season 2010-11, the percentages of parasitism starting by $4.70 \%$ in the second week of November and it increased until reached the peak of $56.85 \%$ in the second week of February. In the second season 2011 -12 , the parasitoid initiated November with a relatively low percentage of 3.94 $\%$ and it gradually increased until reached the maximum of $65.85 \%$ in the first week of March. The results indicated that the rate was relatively higher in 2011-12 than that in 2010-11 (Table 1).

Table (1): Monthly mean percentages of parasitism on B. brassicae by $D$. rapae on cauliflower plants at Sharkia Governorate during the two successive seasons 2010/ 11- 2011/ 12.

\begin{tabular}{|c|c|c|c|c|c|c|c|c|c|c|c|c|}
\hline \multirow{4}{*}{ 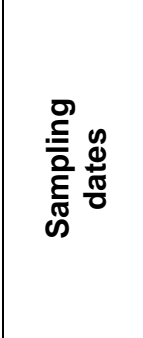 } & \multirow{4}{*}{ 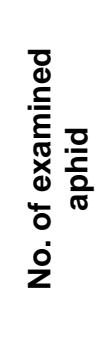 } & \multicolumn{3}{|c|}{$\begin{array}{c}\text { N0. of } \\
\text { parasitoid } \\
\text { aphid } \\
\text { (mummies) }\end{array}$} & \multirow{4}{*}{ 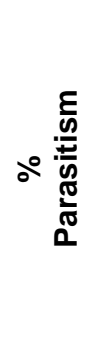 } & \multicolumn{7}{|c|}{ Emerged parasitoids } \\
\hline & & \multirow{3}{*}{ A } & \multirow{3}{*}{ B } & \multirow{3}{*}{ Total } & & \multirow{2}{*}{\multicolumn{2}{|c|}{\begin{tabular}{|c|}
$\begin{array}{c}\text { Primary } \\
\text { parasitoid }\end{array}$ \\
$D$. \\
rapae
\end{tabular}}} & \multicolumn{4}{|c|}{ Hyper parasitoids } & \multirow{3}{*}{ Total } \\
\hline & & & & & & & & \multicolumn{2}{|c|}{$\begin{array}{c}\text { Pachneuron } \\
\text { sp }\end{array}$} & \multicolumn{2}{|c|}{$\begin{array}{l}\text { Alloxysta } \\
\text { sp. }\end{array}$} & \\
\hline & & & & & & $\mathbf{N}$ & R.D\% & $\mathbf{N}$ & R.D\% & $\mathbf{N}$ & $R . D \%$ & \\
\hline Nov.2010 & 508 & 18 & 21 & 39 & 7.68 & 31 & 100 & 0 & 0 & 0 & 0 & 31 \\
\hline Dec. & 540 & 49 & 36 & 85 & 15.74 & 63 & 90 & 5 & 6.67 & 2 & 2.66 & 70 \\
\hline Jan.2011 & 579 & 104 & 71 & 175 & 30.22 & 98 & 66.67 & 38 & 25.85 & 11 & 7.48 & 147 \\
\hline Fab. & 507 & 141 & 73 & 214 & 42.21 & 111 & 64.16 & 45 & 26.01 & 17 & 9.83 & 173 \\
\hline March & 408 & 58 & 32 & 90 & 22.06 & 30 & 37.04 & 39 & 48.15 & 12 & 14.81 & 81 \\
\hline Mean & $\begin{array}{c}508.4 \pm \\
28.29\end{array}$ & & & & $\begin{array}{r}23.58 \pm \\
5.94\end{array}$ & & & & & & & \\
\hline Nov.2011 & 526 & 28 & 26 & 54 & 10.27 & 35 & 100 & 0 & 0 & 0 & 0 & 35 \\
\hline Dec. & 553 & 64 & 47 & 111 & 20.07 & 89 & 100 & 0 & 0 & 0 & 0 & 89 \\
\hline \begin{tabular}{|l|}
$J a n .2012$ \\
\end{tabular} & 595 & 128 & 91 & 219 & 36.81 & 138 & 76.24 & 29 & 16.02 & 14 & 7.74 & 181 \\
\hline Fab. & 520 & 145 & 101 & 246 & 47.31 & 141 & 72.04 & 40 & 18.96 & 19 & 9.00 & 211 \\
\hline March & 356 & 60 & 32 & 92 & 25.84 & 39 & 54.93 & 20 & 28.17 & 12 & 16.9 & 71 \\
\hline Mean & $\begin{array}{l}510 \pm \\
40.6\end{array}$ & & & & $\begin{array}{c}28.06 \pm \\
6.44\end{array}$ & & & & & & & \\
\hline
\end{tabular}

$\mathbf{A}=$ No. of mummified host counted at the date of inspection. N-Number RD= Relative density $\mathrm{B}=\mathrm{No}$. of mummified host appearing during the laboratory rearing 
The total mean parasitism of $D$. rapae were 23.58 and $28.06 \%$ during the two seasons, respectively. According to Stary (1966), Bueno \& Souza (1992), El-Maghraby (1993), Abd El-Megid (1999) and Saleh (2000 \& 2004) $D$. rapae is a primary parasitoid. Pachyneuron aphidis was reported as a hyperparasitoid on D. rapae by Thakur et al. (1989) and Bueno \& Souza (1992). The present results agree with those of Horn (1989) who stated that $D$. rapae parasitized cauliflower and green peach aphids in Ohio and California, were themselves parasitized, mostly by Asaphes lucens and Aphidencyrtus sp.

\section{2- Effect of parasitoid densities on parasitisation rate.}

Data presented in illustrated Table (2) shows that the parasitoid density had influenced on percentage of parasitism, giving maximum percentage of was $87.75 \%$ for $D$. rapae kept at rate of 15 parasitoid females per cage and the minimum was $48.60 \%$ at three parasitoid per cage. There were significant differences in the total numbers of parasitized aphid and the total percentage of parasitism at all densities .The maximum number of parasitized aphids by $D$. rapae (175.5) was recorded at 15 parasitoids per cage and a minimum of 97.2 was recorded at three parasitoid per cage. The highest percentage of adult's emergence was $82.41 \%$ for $D$. rapae at three parasitoid per cage. These findings agree with that of (Sinha and Singh 1979\&1980, El- Naggar et al. 2008 and Ralec et al 2011).

Table (2): Effect of parasitoid density on the number of parasitized aphids, percentage of parasitism and percentage of adult emergence in the field under $19 \pm 1^{\circ} \mathrm{C}$ and $74 \pm 3 \%$ R.H.

\begin{tabular}{|c|c|c|c|c|c|}
\hline \multirow[b]{2}{*}{$\begin{array}{l}\text { Parasitoid } \\
\text { density }\end{array}$} & \multicolumn{5}{|c|}{ Mean \pm SD } \\
\hline & $\begin{array}{l}\text { No. of } \\
\text { emerged } \\
\text { adults }\end{array}$ & $\begin{array}{l}\text { No. of non } \\
\text { emerged } \\
\text { adults }\end{array}$ & $\begin{array}{c}\text { No. of } \\
\text { parasitized } \\
\text { aphid } \\
\text { (Mummies) }\end{array}$ & $\begin{array}{c}\text { Percentage } \\
\text { of } \\
\text { parasitism }\end{array}$ & $\begin{array}{l}\text { Percentages } \\
\text { of adult } \\
\text { emergence }\end{array}$ \\
\hline 3 우 & $80.1 \mathrm{E} \pm 4.89$ & $17.1 \mathrm{D} \pm 2.12$ & $97.2 \mathrm{E} \pm 6.25$ & $48.6 \mathrm{E} \pm 2.96$ & $82.41 \mathrm{~A} \pm 3.11$ \\
\hline 6 오 & $95 \mathrm{D} \pm 3.96$ & $28.5 \mathrm{C} \pm 1.27$ & $123.5 \mathrm{D} \pm 5.21$ & $61.75 \mathrm{D} \pm 2.53$ & $80.13 \mathrm{~B} \pm 2.39$ \\
\hline 9 오 & $112 \mathrm{C} \pm 2.71$ & $32.5 \mathrm{C} \pm 1.41$ & $144.5 \mathrm{C} \pm 4.03$ & $72.25 \mathrm{C} \pm 2.25$ & $76.18 \mathrm{C} \pm 2.02$ \\
\hline 12 우 & $120 \mathrm{~B} \pm 5.21$ & $39.0 \mathrm{~B} \pm 3.22$ & $159 \mathrm{~B} \pm 7.01$ & $79.5 \mathrm{~B} \pm 3.03$ & $73.35 \mathrm{E} \pm 1.68$ \\
\hline 15 우 & $132.1 \mathrm{~A} \pm 8.71$ & $43.4 \mathrm{~A} \pm 6.31$ & $175.5 \mathrm{~A} \pm 5.09$ & $87.75 \mathrm{~A} \pm 2.60$ & $75.27 \mathrm{D} \pm 4.09$ \\
\hline LSD 0.05 & 1.68407 & 4.125106 & 5.179249 & \begin{tabular}{|l|}
0.729223 \\
\end{tabular} & 0.0197474 \\
\hline
\end{tabular}
Means followed by the same letter in a column are not significantly different at $5 \%$ level of probability.

The data in Table (3) showed that release of $D$. rapae at different parasitoid host ratios under green houses on cauliflower plant to control $B$. brassicae during 2010/2011. The lowest total parasitism ratios reached $32.37,19.91,11.80$ and 9.18 with the parasitoid host ratios $1: 4,1: 8,1: 12$, and $1: 16$ respectively after eight days from releasing.

After that the total parasitism ratios increased until reached $100,78.70,73.57$ and $36.62 \%$ at the last same parasitoid ratios respectively after 28 days from released. The average parasitism ratios in green houses were $73.94,60.74,54.29$ and 39.98 at the parasitoid host ratios 1:4, 1:8, 1:12 and $1: 16$ respectively. 
Saleh, A. A. A.

Table (3): Percentages of parasitism on B. brassicae after release of $D$. rapae at different Parasitoid: host ratios under green houses on cauliflower plants during 2010/ 11.

\begin{tabular}{|c|c|c|c|c|c|}
\hline \multirow{2}{*}{$\begin{array}{c}\text { Sampling } \\
\text { dates }\end{array}$} & $\begin{array}{c}\text { Dates } \\
\text { After } \\
\text { Release }\end{array}$ & $\mathbf{1 : 4}$ & $\mathbf{1 : 8}$ & $\mathbf{1 : 1 2}$ & $\mathbf{1 : 1 6}$ \\
\cline { 3 - 6 } & 4 & 0 & 0 & 0 & 0 \\
\hline $16-12-10$ & 8 & 32.37 & 19.91 & 11.89 & 9.18 \\
\hline $20-12$ & 12 & 49.67 & 25.71 & 18.19 & 12.29 \\
\hline $24-12$ & 16 & 68.09 & 36.62 & 23.79 & 15.90 \\
\hline $28-12$ & 20 & 73.48 & 48.2 & 41.58 & 20.13 \\
\hline $1-1-2011$ & 24 & 89.74 & 65.74 & 54.49 & 28.75 \\
\hline $5-1$ & 28 & 100 & 78.70 & 73.57 & 36.62 \\
\hline $9-1$ & 32 & 100 & 93.28 & 81.75 & 58.25 \\
\hline $13-1$ & 36 & 100 & 100 & 92.03 & 78.93 \\
\hline $17-1$ & 40 & 100 & 100 & 100 & 86.6 \\
\hline $21-1$ & 44 & 100 & 100 & 100 & 93.08 \\
\hline $25-1$ & & $73.94 \pm 10.19$ & $60.74 \pm 11.01$ & $54.29 \pm 11.17$ & $39.98 \pm 10.11$ \\
\hline \multicolumn{2}{|r|}{ Average } & & & & \\
\hline
\end{tabular}

The data presented in Table 4: revealed that release of $D$. rapae at parasitoid : host ratios $1: 8$ and 1:12 in the field on cauliflower plant to control $B$. brassicae during 2011-2012. The lowest total parasitism ratios reached 13.32 and 9.69 with the parasitoid host ratios $1: 8$ and 1:12 while in the farmer was $8.44 \%$ after four days from released. On the other hand the total parasitism ratios increased until reached 98.57 and 84.73 with the same parasitoid host ratios $1: 8$ and $1: 12$ while in the farmer was $52.74 \%$ after 40 days. Meanwhile, the average parasitism ratios in the field were 58.39, 50.01 and $32.49 \%$ at the parasitoid host ratios $1: 8,1: 12$ and in the farmer during the period of release. Finally the parasitoid $D$. rapae can be used as biological control agents $B$. brassicae in cauliflower plantation under green houses and under field conditions at the parasitoid host ratios of $1: 8$ and 1:12.

Table (4): Percentages of parasitism on $B$. brassicae after release of $D$. rapae at different parasitoid: host ratios in the field on cauliflower plants during 2011/ 12.

\begin{tabular}{|c|c|c|c|c|}
\hline \multirow{2}{*}{$\begin{array}{c}\text { Sampling } \\
\text { dates }\end{array}$} & $\begin{array}{c}\text { Dates after release } \\
\text { Release }\end{array}$ & \multicolumn{2}{|c|}{ Parasitoid : host ratio } & \multirow{2}{*}{ In the farmer } \\
\cline { 3 - 4 } & 4 & $\mathbf{1 : 8}$ & $\mathbf{1 : 1 2}$ & \\
\hline $15-12-11$ & 8 & 13.32 & 9.69 & 8.44 \\
\hline $19-12$ & 12 & 17.67 & 14.22 & 10.81 \\
\hline $32-12$ & 16 & 20.62 & 16.67 & 14.13 \\
\hline $27-12$ & 20 & 33.88 & 21.68 & 16.44 \\
\hline $31-12$ & 24 & 41.89 & 32.47 & 22.00 \\
\hline $4-1-2012$ & 28 & 51.47 & 40.61 & 27.7 \\
\hline $8-1$ & 32 & 62.68 & 53.07 & 39.22 \\
\hline $12-1$ & 36 & 74.25 & 62.75 & 48.67 \\
\hline $16-1$ & 40 & 86.28 & 70.98 & 45.12 \\
\hline $20-1$ & 44 & 98.57 & 84.73 & 52.47 \\
\hline $24-1$ & 48 & 100 & 93.92 & 48.17 \\
\hline $28-1$ & & 100 & 100 & 56.46 \\
\hline \multicolumn{2}{|l|}{ Average } & 58.39 & 50.01 & 32.49 \\
\hline
\end{tabular}


III. Effect of temperature and relative humidity on the population density of the aphid B. brassicae and its associated parasitoid D.rapae at different parasitoid / host ratios under green houses .

III.1 On B. brassicae in cauliflower at parasitoid/ host ratios 1:4, 1:8, $1: 12$, and $1: 16$.

Data in Table (5) showed that the values of correlation coefficient of the relation between temperature, relative humidity and the population density of $B$. brassicae during the two seasons of study. The minimum temperature induced significant negative correlation but the maximum temperature showed significant positive correlation in the first season. Also the maximum relative humidity showed significant positive correlation in the second season at parasitoid /host ratio 1:4. On the other hand, the minimum and maximum relative humidity cleared significant positive correlation at parasitoid/ host ratio1:8,also the maximum temperature cleared significant positive correlation at parasitoid /host ratio $1: 12$ in the first season. Meanwhile the minimum relative humidity cleared significant positive correlation in the second season 2011(Table 5). The results in Table (6) recorded the population density of B.brassicae during the two year of study. The explained variance of temperature ( $\mathrm{min}$. and max.) tested on the population density of B.brassicae showed an effect ranging from $25.8 \%$ to $22.1 \%, 69.2 \%$ to $2.3 \%, 0.1 \%$ to $24.1 \%$ and $27.3 \%$ to $23.3 \%$ in the first seasons and from $1.0 \%$ to $29.2 \%, 34.2 \%$ to $33.7 \%, 5.6 \%$ to $4.0 \%$ and $2.9 \%$ to $29.2 \%, 34.2 \%$ to $33.7 \%, 5.6 \%$ to $4.0 \%$ and $2.9 \%$ to $14.4 \%$ in second season. Meanwhile the minimum and maximum R.H. varied from $5.0 \%$ To $10.3 \%, 18.9 \%$ to $0.2 \%, 24.1 \%$ to $7.0 \%$ and $1.0 \%$ to $2.0 \%$ in 2010 and from $3.1 \%$ to $46.3 \%, 14.5 \%$ to $8.7 \%, 17.7 \%$ to $10.7 \%$ and $1.8 \%$ to $12.6 \%$ in 2011 season .The combined effect of both factors averaged $82.1 \%, 94.5 \%$ , $41.3 \%$ and $38.2 \%$ in 2011 season and $94.5 \%, 78.6 \%, 64.5 \%$ and $34.5 \%$ in 2011 at the four different parasitoid/ host ratios 1:4,1:8, 1:12 and 1:16, respectively (Table 6) .

Table (5): Simple correlation coefficient between temperature, relative humidity and the total numbers of $B$. brassicae at different parasitoid :host ratios under green houses on cauliflower plants during the two season $2010 / 11$ and $2011 / 12$ at Sharkia Governorate.

\begin{tabular}{|l|c|c|c|c|}
\hline \multirow{3}{*}{ Weather factors } & \multicolumn{4}{|c|}{ correlation coefficient (R) } \\
\cline { 2 - 5 } & \multicolumn{4}{|c|}{$\mathbf{2 0 1 0 - 2 0 1 1}$} \\
\cline { 2 - 5 } & $\mathbf{1 : 4}$ & $\mathbf{1 : 8}$ & $\mathbf{1 : 1 2}$ & $\mathbf{1 : 1 6}$ \\
\hline Min. temp. & $-0.508^{*}$ & -0.226 & 0.316 & -0.258 \\
\hline Max. temp & $0.470^{*}$ & -0.276 & $0.419^{*}$ & 0.483 \\
\hline Min. R.H. & -0.366 & $0.600^{*}$ & -0.106 & $-.0567^{*}$ \\
\hline Max. R.H. & 0.077 & $0.522^{*}$ & -0.104 & 0.074 \\
\hline \multicolumn{5}{|c|}{$2011-2012$} \\
\hline Min. temp. & -0.162 & 0.227 & -0.020 & 0.061 \\
\hline Max. temp & -0.344 & -0.217 & 0.073 & 0.179 \\
\hline Min. R.H. & -0.238 & -0.381 & -0.421 & 0.545 \\
\hline Max. R.H. & $0.681^{*}$ & 0.095 & 0.304 & 0.088 \\
\hline
\end{tabular}


Saleh, A. A. A.

Table (6): Numerical relation between temperature, relative humidity and the the total numbers of $B$. brassicae at Sharkia Governorate during the two season 2010/11 and 2011/ 12.

\begin{tabular}{|c|c|c|c|c|c|c|c|c|}
\hline \multirow{3}{*}{$\begin{array}{c}\text { Weather } \\
\text { A:Simple }\end{array}$} & \multicolumn{8}{|c|}{ Regression equation (B. brassicae) } \\
\hline & \multicolumn{2}{|c|}{$1: 4$} & \multicolumn{2}{|c|}{$1: 8$} & \multicolumn{2}{|c|}{\begin{tabular}{|r|}
$1: 12$ \\
\end{tabular}} & \multicolumn{2}{|c|}{ 1:16 } \\
\hline & $\begin{array}{c}2010-11 \\
R^{2}\end{array}$ & $\begin{array}{c}2011-12 \\
R^{2}\end{array}$ & $\begin{array}{c}2010-11 \\
R^{2}\end{array}$ & $\begin{array}{c}2011-12 \\
R^{2}\end{array}$ & $\begin{array}{c}2010-1 \\
R^{2}\end{array}$ & $\begin{array}{l}2011-1 \\
R^{2}\end{array}$ & $2010-1$ & $\begin{array}{l}2011-12 \\
R^{2}\end{array}$ \\
\hline Min. temp. & 0.258 & 0.001 & $0.692^{\star}$ & 0.342 & 0.010 & 0.056 & 0.273 & 0.029 \\
\hline Max. temp & 0.221 & 0.292 & 0.023 & 0.337 & 0.241 & 0.040 & 0.233 & 0.144 \\
\hline Min. R.H. & 0.005 & 0.031 & 0.189 & 0.145 & 0.001 & 0.177 & 0.001 & 0.018 \\
\hline Max. R.H. & 0.103 & $0.463^{*}$ & 0.020 & 0.087 & 0.070 & 0.107 & 0.020 & 0.126 \\
\hline B: Multiple & $0.821^{*}$ & $0.945^{\star}$ & $0.945^{\star}$ & $0.786^{*}$ & 0.413 & 0.645 & 0.382 & 0.345 \\
\hline
\end{tabular}

III.2 On $D$.rapae in cauliflower at parasitoid / host ratios 1:4, 1:8, 1:12 and $1: 16$.

The results in Table (7) showed that the values of correlation coefficient of the relation between temperature, relative humidity and the population density of $D$.rapae during the tow years of study. The minimum temperature cleared highly significant negative correlation, also the minimum relative humidity cleared significant negative correlation in the first season at parasitoid /host ratio 1:4. Meanwhile, the maximum temperature cleared highly significant negative correlation at at parasitoid/ host ratio1:8 and significant negative correlation at parasitoid /host ratio 1:16 in the first season. While the temperature and relative humidity exerted wide effect ranging from slight negative to positive correlation in the second season at different parasitoid / host ratios (Table 7).

Table (7): Simple correlation coefficient between temperature, relative humidity and the total numbers of $D$. rapae at Sharkia Governorate during the two season 2010/ 11 and 2011/ 12.

\begin{tabular}{|c|c|c|c|c|}
\hline \multirow{2}{*}{ Weather factors } & \multicolumn{4}{|c|}{ correlation coefficient (R) } \\
\cline { 2 - 5 } & $\mathbf{4}$ & $\mathbf{1 : 4}$ & $\mathbf{1 : 1 2}$ & $\mathbf{1 : 1 6}$ \\
\cline { 2 - 5 } & $-0728^{* *}$ & -0.334 & -0.018 & -0.413 \\
\hline Max. temp & -0.049 & $-0.782^{* *}$ & -0.363 & $-0.580^{*}$ \\
\hline Min. R.H. & $-0.574^{*}$ & 0.160 & -0.422 & -0.265 \\
\hline Max. R.H. & -0.196 & 0.264 & -0.431 & -0.076 \\
\hline \multicolumn{5}{|c|}{$2011-2012$} \\
\hline Min. temp. & -0.069 & 0.184 & -0.012 & 0.029 \\
\hline Max. temp & -0.425 & -0.319 & 0.032 & 0.379 \\
\hline Min. R.H. & 0.339 & -0.296 & 0.396 & 0.065 \\
\hline Max. R.H. & 0.323 & 0.184 & 0.167 & -0.136 \\
\hline
\end{tabular}

The data in Table (8) illustrated the numerical relation between temperature relative humidity and population density of $D$. rapae during the tow seasons of study. The explained variance of temperature (min. and max.) tested on the population density of D.rapae showed an effect ranging from $53.0 \%$ to $13.2 \%, 2.6 \%$ to $61.2 \%, 10.6 \%$ to $22.2 \%$ and $17.4 \%$ to $33.6 \%$ in the first season ,and from $15.3 \%$ to $18.1 \%, 23.1 \%$ to $10.2 \%, 1.0 \%$ to 16.8 
$\%$ and $17.8 \%$ to $4.9 \%$ in the second season. Meanwhile, the minimum and maximum R.H. varied from $33 \%$ to $3.0 \%, 13.5 \%$ to $2.5 \%, 14.0 \%$ to $18.5 \%$ and $2.9 \%$ to $1.1 \%$ in 2010 . The combined effect of both factors averaged $90.6 \%, 62.3 \%$ and $71.1 \% 97.7 \%$ in the first season and $68.4 \%, 88.1 \%, 67.1 \%$ and $81.6 \%$ in the second season at the four different parasitoid/ host ratios $1: 4$, 1:8, 1:12 and 1:16, respectively (Table 8).

Table (8): Numerical relation between temperature, relative humidity and the the total numbers of $D$. rapae at Sharkia Governorate during the two season 2010/ 11 and 2011/ 12.

\begin{tabular}{|c|c|c|c|c|c|c|c|c|}
\hline $\begin{array}{r}\text { Weather } \\
\text { factors }\end{array}$ & \multicolumn{9}{|c|}{$\mathbf{1 : 4}$} & \multicolumn{2}{|c|}{$\mathbf{1 : 8}$} & $\mathbf{1}$ & \multicolumn{2}{|c|}{$\mathbf{1 : 1 6}$} \\
\cline { 2 - 9 } Seasons & $\begin{array}{c}\mathbf{2 0 1 0 - 1 1} \\
\mathbf{R}^{\mathbf{2}}\end{array}$ & $\begin{array}{c}\mathbf{2 0 1 1 - 1 2} \\
\mathbf{R}^{\mathbf{2}}\end{array}$ & $\begin{array}{c}\mathbf{2 0 1 0 - 1 1} \\
\mathbf{R}^{\mathbf{2}}\end{array}$ & $\begin{array}{c}\mathbf{2 0 1 1 - 1 2} \\
\mathbf{R}^{\mathbf{2}}\end{array}$ & $\begin{array}{c}\mathbf{2 0 1 0 - 1 1} \\
\mathbf{R}^{\mathbf{2}}\end{array}$ & $\begin{array}{c}\mathbf{2 0 1 1 - 1 2} \\
\mathbf{R}^{\mathbf{2}}\end{array}$ & $\begin{array}{c}\mathbf{2 0 1 0 - 1 1} \\
\mathbf{R}^{\mathbf{2}}\end{array}$ & $\begin{array}{c}\mathbf{2 0 1 1 - 1 2} \\
\mathbf{R}^{\mathbf{2}}\end{array}$ \\
\hline $\begin{array}{c}\text { A:Simple Min. } \\
\text { temp. }\end{array}$ & 0.530 & 0.153 & 0.026 & 0.231 & 0.106 & 0.100 & 0.174 & 0.178 \\
\hline Max. temp & 0.132 & 0.181 & 0.612 & 0.102 & 0.222 & 0.168 & 0.336 & 0.049 \\
\hline Min. R.H. & 0.330 & 0.140 & 0.135 & 0.150 & 0.140 & 0.053 & 0.029 & 0.297 \\
\hline Max. R.H. & 0.030 & 0.102 & 0.025 & 0.135 & 0.185 & 0.005 & 0.011 & 0.134 \\
\hline B: Multiple & 0.906 & 0.684 & 0.977 & 0.881 & 0.623 & 0.671 & 0.711 & 0.816 \\
\hline
\end{tabular}

III.3 On B. brassicae and D.rapae in cauliflower at parasitoid / host ratios 1:8and1:12 in field .

The results in Table (9) showed that the values of correlation coefficient of the relation between temperature, relative humidity and the population density of B.brassicae and D.rapae during 2011-2012season.The temperature exerted a wide effect ranging from slight positive to negative correlation in D.rapae. The maximum relative humidity cleared highly significant negative correlation in B.brassicae at parasitoid /host ratio 1:4 and slightly negative correlation in D.rapae at parasitoid /host ratio 1:8.

Table (9): Simple correlation coefficient between temperature, relative humidity and the total numbers of $B$. Brassicae and $D$. rapae during the season 2011 at parasitoid :host ratios1:4 and $1: 8$ in field.

\begin{tabular}{|c|c|c|}
\hline \multirow{2}{*}{ Weather factors } & \multicolumn{2}{|c|}{ correlation coefficient (R) } \\
\cline { 2 - 3 } & \multicolumn{2}{|c|}{ B. brassicae } \\
\cline { 2 - 3 } & $\mathbf{1 : 8}$ & $\mathbf{1 : 1 2}$ \\
\hline Min. temp. & 0.315 & -0.326 \\
\hline Max. temp & -0.054 & -0.259 \\
\hline Min. R.H. & 0.272 & -0.362 \\
\hline Max. R.H. & $-0.678^{* *}$ & 0.113 \\
\hline Min. temp. & D. rapae & 0.005 \\
\hline Max. temp & 0.402 & 0.422 \\
\hline Min. R.H. & 0.186 & $-0.524^{*}$ \\
\hline Max. R.H. & -0.262 & -0.137 \\
\hline
\end{tabular}


The data in Table (10) illustrated the numerical relation between temperature relative humidity and population density of $B$. brassicae and $D$. rapae during 2011 season. The explained variance of temperature (min. and max.) tested on the population density of $B$.brassicae and $D$. rapae had exerted effect ranged from $2.0 \%$ to $1.0 \%, 3.4 \%$ to $4.9 \%$ and $9.9 \%$ to $2.8 \%, 16.1$ $\%$ to $3.7 \%$ in B.brassicae and D. rapae at parasitoid / host ratios 1:4and1:8 , respectively. Meanwhile, the minimum and maximum R.H. varied from $13.1 \%$ to $15.1 \%, 27.5 \%$ to $26.2 \%$ and $1.0 \%$ to $46 \%, 14.3 \%$ to $14.9 \%$ in B.brassicae and $D$. rapae at parasitoid / host ratios 1:4and1:8, respectively. The combined effect of both factors averaged 55.8\%, 56.8 \%and52.4 \%, 52.0\% in $B$.brassicae and $D$. rapae at parasitoid / host ratios 1:4and1:8, respectively.

Table (10): Numerical relation between temperature, relative humidity and the total numbers of $B$. Brassicae and $D$. rapae during the season 2011 at parasitoid :host ratios 1:8 and1:12 in field.

\begin{tabular}{|c|c|c|c|c|}
\hline \multirow{2}{*}{$\begin{array}{c}\text { Weather } \\
\text { A:Simple }\end{array}$} & \multicolumn{3}{|c|}{ correlation coefficient (R) } \\
\cline { 2 - 5 } & $\mathbf{2}$ B. brassicae & $\mathbf{1 : 8}$ & $\mathbf{1}$ & $\mathbf{1}$ \\
\cline { 2 - 5 } & $\mathbf{1 : 4}$ & 0.098 & 0.0340 & 0.161 \\
\hline Min. temp. & 0.020 & 0.028 & 0.049 & 0.037 \\
\hline Max. temp & 0.010 & 0.001 & 0.275 & 0.143 \\
\hline Min. R.H. & 0.131 & 0.460 & 0.262 & 0.149 \\
\hline Max. R.H. & 0.151 & 0.524 & 0.568 & 0.520 \\
\hline B: Multiple & 0.558 & & & \\
\hline
\end{tabular}

\section{REFERENCES}

Abou-Fakar, E. M. and N. S. Kawar 1998. Complex of end parasitoids of aphids (Homoptera : Aphidiidae) on vegetable and other plants. Entomologicheskoe Obozrenie, 77 (4):753-763.

Bueno V. H. P. and B. M. D. Souza 1992. Ethnology and life span of Diaeretiella rapae' (Hymenoptera: Aphidiidae). Revista de Agricultura (Piracicaba), 67 (1): 49-59.

Costat, Software 1990. Micro Computer Program Analysis version4-20, CoHort Software, Berkly, C A.

El- Maghraby, M. M. A. 1993. Yearly abundance of the cruciferous aphid Brevicoryne brassicae L. (Homoptera, Aphidiidae) in relation to the primary and Hyperparasitoids on cauliflower in Zagazig region, Egypt. Zagazig, J. Agric., Res., 20 (5):1627-1639.

El-Heneidy; A. H.; Gonzalez; D.; Ahmed; M. A.; Ibraheem; M. M.; Megahed; H. E.; Abdel-Awal; W. M. and Adly; D. 2006. Performance of certain exotic aphid parastoid species towards cereal aphids under laboratory, field cage and open wheat field conditions in Egypt. Egyptian Journal of Biological Pest Control, 16(2): 67-72.

Elliott, N. C., French, B. W., Reed, D. K., Burd, J. D. and Kindler, S. D. 1994. Host species effects on parasitization by a syrian population of Diaeretiella rapae M'Intosh (Hymenoptera: Aphidiidae) Can. Entomol. $126,1515-1517$. 
El-Naggar, E. M., A. M Abou El-Naga, A. A. Ghanim and A. A. Saleh 2008. Mass production and field application of some aphid natural enemies. J. Agric. Res., 86(2):623-634. Entomol. Soc. 62. (2): 203-210.

Farrell, J. A. and M. W. Stufkens 1990. The impact of Aphidius rhopalosiphi (Hymenoptera: Aphidiidae) on population of the rose grain aphid, Metoplophium dirhodum (Homoptera: Aphidiidae) on cereals in cankrbury. Newzeland. Bull. Entomol. Res., 80:337-383.

Hafez, M. 1965. Characteristics of the open empty mummies of the cabbage aphid, Brevicoryne brassicae L. indicating the identify of emerged parasites. Agric. Res., Rev., 43:85-88.

Herakly, F. A. and A. Abou El-Ezz 1970. Seasonal abundance and natural enemies of the cabbage aphid, Brevicoryne brassicae L. Agric., Res. Rev. ,48:119-122.

Horn, D. J. 1989. Secondary parasitism and population dynamics of aphid parasitoids (Hymenoptera: Aphidiidae). J. Kansas. Entmol. Soc. 62(2):203 - 210.

Pike, K. S., Stary, P., Miller, T., Allison, D., Graf, G., Boydston, L., Miller, R. and Gillespie, R. 1999. Host range and habitats of the aphid parasitoid Diaeretiella rapae (Hymenoptera: Aphididae) in Washington State. Environ. Entomol. 28, $61-71$.

Ralec, A.;A. ; A. Bibule; A. Barragan and Y. Qutraman (2011). Host range limitation caused by incomplete host regulation in an aphid parasitoid. Journal of Insect Physiology. 57:3, 363-371.

Saleh, A. A. A. 2000. Ecological and biological studies on certain aphid, parasites at Mansoura district. M.Sc. Thesis, Fac., of Agric., Mansoura Univ.,PP85.

Saleh, A. A. A. 2004. Mass production and field application of some aphid natural enemies. Ph.D. Thesis, Fac. of Agric., Mansoura Univ., pp 161.

Saleh, A. A. A. 2008. Ecological and biological studies of Diaeretiella rapae (M'Intosh) (Hymenoptera: Aphidiidae), the parasitoid of some aphid species in Egypt. Egyptian Journal of Biological Pest Control, 18 (1):3338.

Saleh, A. A. A., M. S. Hashem and A. A. Abd-Elsamed. 2006. Aphidius colemani Viereck and Diaretiella rapae ( $\mathrm{M}^{\prime}$ ' Intosh) as parasitoids on the common reed aphid, Hyalopterus pruni (Geoffroy) in Egypt. Egyptian Journal of Biological Control, 16 (2): 93-97.

Saleh; A. A. A. and Gatwary; W. G. T. 2007. Seasonal abundance of the oleander aphid Aphis nerii Boyer de Fonscolombe (Homoptera, Aphididae) in relation to the primary and hyperparasitoid on dafla in Egypt. J. Product \& Dev., 12(2): 709-730.

Sinha, T. B. and R. Singh 1979. Studies on the bionomics of Trioxys indicus (Hymenoptera:Aphidiidae): Effect of population densities on sex ratio Entomophaga 24 (3): 289-294. 
Saleh, A. A. A.

Sinha, T. B. and R. Singh 1980.Studies on the bionomics of Trioxys indicus Subba Rao and Sharma (Hymenoptera:Aphidiidae): A parasitoid of Aphis craccivora Koch(Homoptera: Aphidiidae) the area of discovery of parasitoid. Zetschrift fur Angewandte Entomologie, 89 (2):173-178.

Stary, P. 1966. Aphid parasites of Czechoslovakia. A review of the Czechoslovakia Aphidiidae (Hymenoptera). The Hague, Junk. 242.PP.

Thakur, J. N. Rawat, U. S. Pawar, A. D. and S. Sidhu 1989. Natural enemy complex of the cabbage aphid, Brevicoryne brassicae L. (Homoptera: Aphidiidae) in Kull Valley, Himachol Pradesh. J. Biol. Cont., 3 (1):69.

EVALUATION OF RELEASE OF Diaeretiella rapae (M' INTOSH) FOR CONTROLLING THE CRUCIFEROUS APHID, Brevicoryne brassicae L. ON CAULIFLOWER PLANTS AT SHARKIA GOVERNORATE, EGYPT. تقييم اطلاق الطفيل Diaretiella rapae على نباتـات القرنبيط لمكافحة من فن

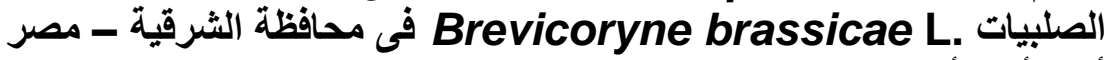
معهل بحوث وقاية النباتات ، مركز البحوث الزراعية ـ الجيزة -مصر

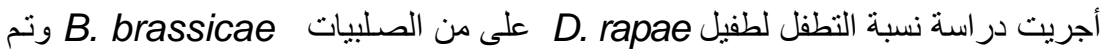

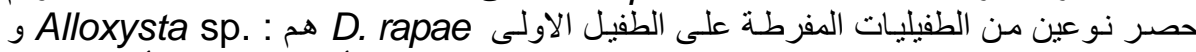
Pachyneuron sp. السنوي لنسبة التطفل هى 23.58\% 28 \% 28.06\% بينما كان المتوسط السنوى لنسبة الطفيليات المفرطة هى 28.42\% , 29.67\% خلال موسمى الدراسة على التو الى .

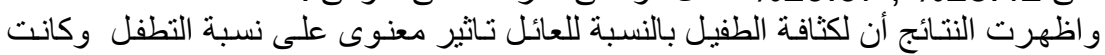

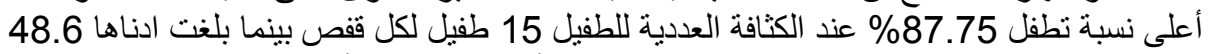

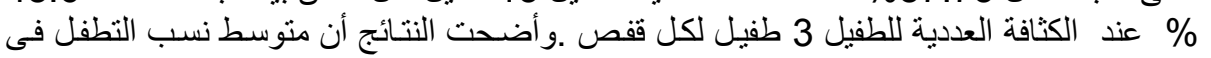

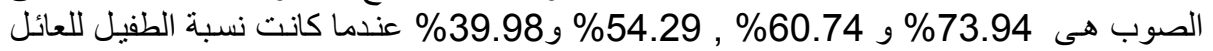

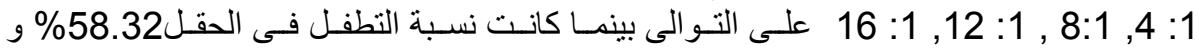

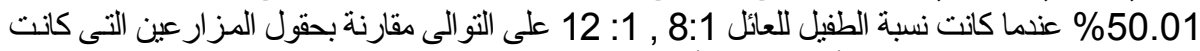

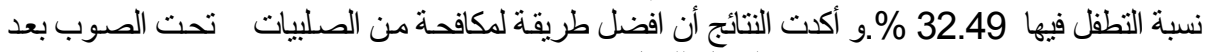

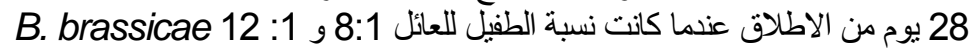

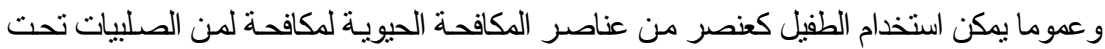
ظروف الحقل والصوب عند نسبة الطفيل للعائل $8: 1$, 1: 12.

كلية الزراعة - جامعة المنصورة كلية الزراعة - جامعة القاهرة
قام بتحكيم البحث

أ.ـد / عبد البديع عبد الحميد غانم

أ.د / محمود السيد نور عبد البد 